\title{
THE PAU-PAUNNA INDALE PATARA: SUFISM AND THE BUGIS ADAPTION AND TRANSFORMATION OF THE HIKAYAT INDERAPUTERA
}

\author{
Nurhayati Rahman ${ }^{* 1}$ \\ Fakultas Ilmu Budaya, Hasanuddin University, \\ Jalan Perintis Kemerdekaan KM 10, \\ Makassar, Sulawesi Selatan, Indonesia \\ email: galigo_2011@yahoo.com
}

Published online: 15 September 2016

To cite this article: Rahman, N. 2016. The pau-paunna Indale Patara: Sufism and the Bugis adaption and transformation of the Hikayat Inderaputera. In Orality, writing and history: The literature of the Bugis and Makasar of South Sulawesi, ed. Druce, S. C. International Journal of Asia Pacific Studies 12 (Supp. 1): 169-186, http://dx.doi.org/10.21315/ijaps2016.12.s1.8

To link to this article: http://dx.doi.org/10.21315/ijaps2016.12.s1.8

\begin{abstract}
The pau-paunna Indale Patara is a Bugis literary work about the vicissitudes and quest of a young prince, written in free prose style with beautiful language. The story is based on the well-known Malay hikayat Inderaputera, itself derived from an earlier Indian work, but was adapted and transformed by the Bugis in order to make it meaningful to their own society. In this article, I discuss various cultural concepts that the Bugis introduced and embedded within the story and manifest in the character of the hero, Indale Patara. In the story, these concepts interact with the mystical form of Islam that the South Sulawesi rulers converted to at the beginning of the 17th century. In particular, Ibn al-Arabi's concept of the "perfect man." I demonstrate the Sufi aspects of the story and show that only by combining Islamic and Bugis qualities and characteristics could Indale Patara become the perfect man.
\end{abstract}

Keywords: Bugis literature, Bugis cultural concepts, perfect man, Sufism, pau-paunna Indale Patara 
The pau-paunna Indale Patara (PPIP) is a Bugis literary work that tells of a heroic fantasy about the vicissitudes and quest of a young prince. The story did not originate among the Bugis but came to South Sulawesi via Malays from the western part of the Indonesian-Malay Archipelago, where it is known as the hikayat Inderaputera. The Malays probably received the story from Indians, as the hikayat Inderaputera is based on an Indian literary work that spread to numerous parts of Southeast Asia. ${ }^{2}$ The story first appears to have entered the rich corpus of oral and written Bugis literature about the time the Bugis and Makasar began to convert to Islam at the beginning of the 17 th century. ${ }^{3}$ The Bugis later adapted the story to their own language, culture and needs, transforming it into a Bugis literary, cultural and religious work through which can be seen the manifestation of the union between indigenous Bugis culture and the mystical form of Islam to which the South Sulawesi elite converted. The story remained popular among the Bugis until the 1940s and was told or read aloud during various cultural and religious celebrations Tol (2008: 3 ).

While the hikayat Inderaputera has been the subject of several academic studies and is widely known among Malay literary specialist (see Mulyadi 1983; Braginsky 2004: 385-399; and Mulyadi and Braginsky 2007), the PPIP is little known outside South Sulawesi. This article represents the first English language study of the PPIP and its aim is to demonstrate how the Bugis adapted and transformed the story to make it meaningful and relevant to their own culture. Below I highlight and explain various distinct Bugis cultural concepts found in the story that manifest in the character of Indale Patara and the Sufi allegories and concepts with which they intertwine. This includes what appears to be the Bugis cultural interpretation and adaption Ibn al-Arabi's Sufi concept of Al-Insan al-Kamil, the "perfect man."

The primary source for the study is a 185-page Bugis language and script manuscript written in free prose with beautiful language. The manuscript was microfilmed in 1991 by the Makassar Branch of the Indonesian National Archives and its catalogue number is No. 01 /MKH/ 1/Arnas/UP Rol 04 No. 1 (Paeni et al. 2003: 5). ${ }^{5}$ I begin with a short synopsis of the PPIP, a full Indonesian translation and transcription of the manuscript is presented in Nurhayati Rahman (2014). ${ }^{6}$ 


\section{SYNOPSIS}

Bukeroma Bisepa, the raja of Samanta Pura, wants to have a child. $\mathrm{He}$ orders his 40 ulama (Islamic scholars) and 40 shaman to request a child from God. After a three-year pregnancy, his 200-hundred-year-old wife gives birth to a truly beautiful boy called Indale Patara and his twin, a kris (dagger) called Sikale Maésani. Fatahule Arifina, the head of the 40 ulama, warns the raja never to give Indale Patara a toy in the shape of an animal.

Indale Patara studies religion and religious sciences with Fatahule Arifina and then male skills with others. One day Indale Patara meets the Prophet Khaidir ${ }^{7}$ in the forest who tells him that he will face many challenges and difficulties in his life but will eventually be happy. Despite his young age, Indale Patara's father makes him king of Samanta Pura.

Indale Patara's travels begin when Raja Bukeroma Bisepa gives him a toy peacock that comes to life and flies Indale Patara to the house of the kind Kajao Pallaq, who looks after him and later takes him to meet Raja Sahesiya. The raja and his prime minister constantly assess and test Indale Patara's behaviour and manners. His good looks infatuate many women and this tests his faith.

Indale Patara takes up the quest to find Raja Sahesiya a potion that will make his wife pregnant. In the first part of the quest, he faces and defeats many ferocious wild animals and the evil Nenek Pakande, finds hidden treasure on a mountaintop, meets a dead person who can talk and a stingray that guards the sea. He arrives in a country where the people worship idols and converts their ruler, Raja Baredaiya, to Islam.

He travels to other lands and sometimes fights in wars not of his making. He is continually tested and at times subject to mistreatment and accusations, but never acts wrongly or selfishly and is exemplary in his conduct and religious faith. He marries three times before returning to Raja Sahesiya with the potion.

The ministers in Raja Sahesiya's land are envious of Indale Patara and plot to poison the white lotus flower he brought that is the potion. Raja Sahesiya's wife becomes pregnant. Two of her ladies in waiting also fall pregnant after eating what is left of the potion and Indale Patara is accused of impregnating them. All three are thrown into the sea to drown as punishment. Indale Patara survives and returns to Kajao Pallaq's house. Meanwhile, the queen gives birth to Princess Mangendare Saheri Bunga, who has a skin disease that is difficult to cure.

The group ministers and nobility scheme against Indale Patara. $\mathrm{He}$ defends himself against them and wins sword and spear fights. They find a 
way to murder him but his wives bring him back to life. They murder him a second time, again his wives bring him back to life. The ministers and nobles challenge him to shoot arrows and grow increasingly resentful as he defeats them all. Indale Patara marries Princess Mangendare Saheri Bunga and the ministers and nobles finally give up. Indale Patara and his wives go to Samanta Pura and he is reunited with his parents.

\section{FROM INDIA TO THE MALAYS}

Most scholars argue that the Malay hikayat Inderaputera originated in Hindu culture and several claim to have identified various Hindu elements that were retained in the story after the Malays converted to Islam, perhaps because these elements remained embedded in Malay culture. For example, Ali Ahmad (1975: xii) identifies the following Hindu influences in the story: the name Indera Putera is derived from a Hindu god, the veneration of deities to obtain powers, the importance of various magical objects such as bezoar stones, the character Berma Sakti mirrors the Hindu God Brahma, and various animal symbols that are sacred in Hindu mythology, such as the peacock and the white lotus flower.

Ahmad (1975: xiv) argues that the Inderaputera story was known among the Malays when they still followed Indic religions and that they introduced various Islamic elements after their conversion to Islam. According to Ahmad, these are evident in the great praise given to God by his creations, the use of the name Allah several times and the appearance of Islamic and Persian names, such as Raja Tahir Syah, Indra Jilani and Nobat Rom Syah. Mulyadi (1983: 38) also argues that the hikayat Inderaputera was known in the archipelago before conversion to Islam and that even after the Malays converted to the new religion an earlier Hindu work still existed in the archipelago. Her argument is based on a statement by Nuruddin AlRaniri, the great 17th century Gujerat Islamic mystic and scholar who worked at the Aceh court. In his 1643 book, Sirat al-Mustakim, Nuruddin Al-Raniri wrote that "we should use books that have no value in Islamic law, such as the Hikayat Sri Rama, the Hikayat Indraputra and suchlike, as toilet paper as they do not contain Allah's name" (Mulyadi 1983: 38). Mulyadi thus considers Al-Raniri's statement indicates that before his death in 1658 there were versions of the hikayat Inderaputera that contained no reference to the Islamic God. ${ }^{8}$ Braginsky (2007: iii), however, disputes this interpretation. He argues that the hikayat Inderaputera came to the Indonesian-Malay Archipelago after the Malays had begun to convert to Islam and that Indian Muslims first undertook Islamisation of the story and 
later brought it to the archipelago where it was reshaped into a Malay Islamic literary work.

Regardless of whether it was the Malays who first introduced the Islamic elements, there is no debate that they adapted and transformed the story to their own culture. Indeed, the hikayat Inderaputera became one of the most widespread and popular stories in the archipelago that, according to Braginsky (2007: i-ivi), should be regarded as one of the great Malay literary works. Braginsky further argues that its great strengths are high aesthetic and Sufi allegories that were capable of influencing readers and listeners and may have aided the process of Islamisation in the archipelago.

\section{THE BUGIS ADAPTION AND TRANSFORMATION OF THE PAU-PAUNA INDALE PATARA}

In the PPIP, the character of Indale Patara is without flaw and as close to perfection as possible. As he travels from one land to another seeking a potion for Raja Sahesiya the people he meets are astonished by his extraordinary good looks, manners, intelligence, great moral character and his exemplary devotion to God. This journey is not simply physical but also a spiritual one that leaves religious, moral and humanitarian messages for the audience in every place the hero visits. However, it is only through an understanding of various Bugis cultural concepts that we can fully understand Indale Patara's character and how the Bugis have adapted and transformed the story. In this section I discuss the following cultural concepts that appear in the PPIP but are absent from the Malay version: siriq (self-worth, shame), sulapaq eppaq (the four sides), the concept of tomanurung, the kris and the notion of a non-human twin. These cultural concepts appear throughout the story in relation to Indale Patara, several of which are set out at the beginning before Indale Patara's birth:

[Fatahule Arifina] sat and prayed. Suddenly the Prophet Khaidir appeared and greeted him, saying: "Fatahule Arifina, in the future there will be a prince of Samanta Pura called Indale Patara who will be born with a kris as his twin. He will have all the greatness and qualities of the sulapaq eppaq (the four sides)."

Tudanni mabbaca doang natakko pole muna Nabi Héléréq bérésellengiwi makkedaé: É Fatahule Arifina engkamua tu matuq anaqna datué ri Samanta pura orowané riaseng Endare 
Patara, najaji silong tappiq napunnaiwi alebbirengngénatettongi sulapaq eppaqé.

Traditionally the Bugis believe that a person can be born together with a non-human twin. Mostly such twins are in the form of an animal, usually a monitor lizard or crocodile, or less commonly a natural or magical object such as a kris. The kris as a birth twin is found only in Bugis traditions about rulers and its gender, as with Indale Patara's twin, is consistently male. Traditionally a kris is considered an important part of male Bugis manhood and masculinity. Indeed, without a kris attached to his waist a man was not considered fully dressed and to separate him from his kris is to separate him from his manhood. In ideal Bugis culture the kris is not used arbitrarily as violence and conflict should be avoided whenever possible through compromise and negotiation. However, when compromise and negotiation have failed the kris can be used in defence. ${ }^{9}$ Ideally, use of the kris must be governed by four related ideal values: intelligence, bravery, honesty and self-control. Misuse of a kris can violate siriq (see below) and adat, leading to the actor being condemned, ostracised or even exiled by the community. In the PPIP, Indale Patara's kris twin, Sikale Maésani, not only enhances his extraordinary physical appearance but whenever used consistently conforms to this ideal Bugis culture, used righteously and in defence of the truth when no other options are left.

In addition to a kris as a twin, the Prophet Khaidir also makes known that Indale Patara will be born with all honour of the sulapaq eppaq. The sulapaq eppaq articulates the Bugis concept of perception as a person, or object, should consist of four sides in order to be complete, or perfect. ${ }^{10}$ For a man there are four specific qualities, as set out in the figure below. ${ }^{11}$

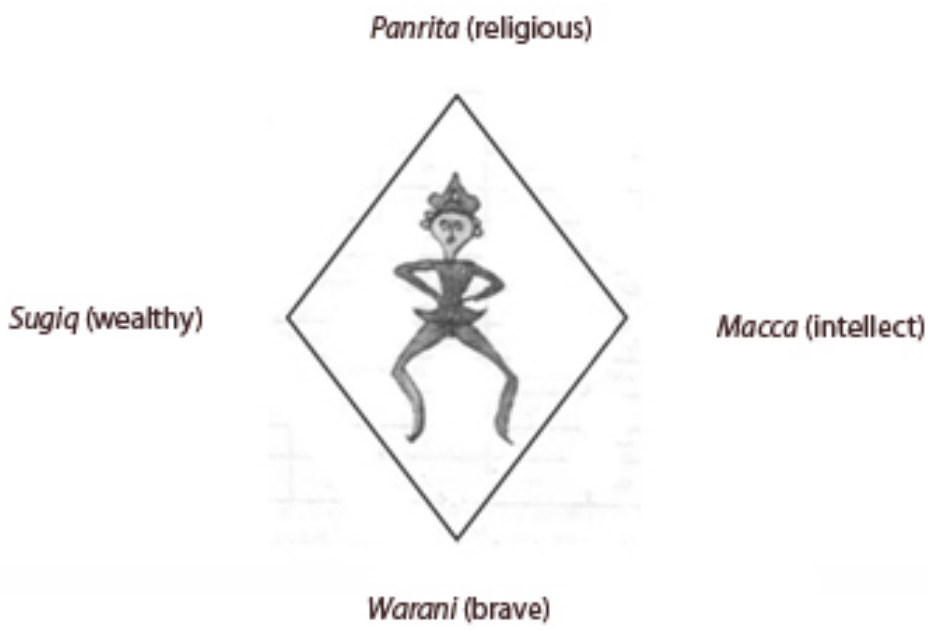

Figure 1: The four sulapaq eppaq qualities for males. 
Men who have the quality warani in the context of sulapaq eppaq are leaders who should fear nothing and be able to defend their family, community, convictions and even faith through both actions and words. To have the quality macca a man must have great intellect and knowledge, be a role model for others and leader. Those who have the quality sugiq possess the ability to become rich, support their family and be a patron for others. The quality panrita relates to men who have great religious learning, are exemplary in their religious practice, trust and devotion to God and be religious leaders. It is considered rare in Bugis culture for a person to have all four sulapaq eppaq qualities and traditionally they would be from the ruling elite. However, it is important for a male to have at least one of the qualities (Rahman 2006: 399). As we have seen, the mystical Prophet Khaidir foretold that Indale Patara would be born with these four qualities of the perfect Bugis man. That he has these qualities is reiterated consistently throughout the story, as in the example below:

The Prime Minister respectfully said: "My lord, I compare Indale Patara to a full moon. The later the night the more radiant he is, the older he grows the more he gleams and he is ever more handsome. There can no longer be any doubt, my lord, Indale Patara is descended from a [to]manurung, [he is] the child of a great king, a wise ulama, brave, and has all the sulapaq eppaq qualities.

Nasompana paredana matarié makkeda: uébaraqi Puang uleng tépu Indale Patara pédéq malalengngi wennié pédéq araingngi attappaqna pédéq laoi taungngé pédéq araiangngi accaiyyana enrengngé akessingenna. Deqna abata-batangenna Puang Indale Patara wija manurung, anaq arung mangkauq, parinta nasulesana, warani to i natettongi sulapaq eppaqé.

The above passage introduces a further Bugis concept, that of the tomanurung. In Bugis oral and written genealogies and traditions, the ruling elite of kingdoms trace their origin to a tomanurung, a class of "whiteblooded" founders who descended from the Upperworld to rule over the common people. Tomanurung are generally male and the female equivalent are totompoq, who ascended from the Underworld (Druce 2009: 161). ${ }^{12}$ In traditional Bugis society status was ascribed at birth and in theory, only the pure whiteblooded descendants of tomanurung and totompoq could become a ruler. The interpolation of this concept into the story remodels the character of Indale Patara to ideal Bugis conceptions of nobility and 
rulership, providing him with the highest status possible by giving him whiteblood. As with the sulapaq eppaq qualities, his descent from a tomanurung is reaffirmed at various times in the story and "Even from afar one can tell that he (Indale Patara) is descended from a tomanurung" (Mabéla mupa namarissengngeng wija manurung arung mangkauq).

Another important Bugis cultural concept constantly associated with Indale Patara is siriq. ${ }^{13}$ This concept, which is deeply embedded in Bugis culture, refers to the self-worth, self-respect, and the honour of a person or their wider community. For the Bugis, their siriq must be defended at all costs to avoid shame. Some writers have even argued that for the Bugis there is nothing more important in this world than siriq and all can be sacrificed in its defence, including their lives, while those who do not feel siriq are said to be little more than animals in human form (Hamid 1985: 37). Ideally, a person's behaviour, speech and actions are also governed by siriq and this should encompass self-restraint and not to be boastful or show off, all of which are considered inappropriate. This is set out in the PPIP where it is stated that "A man with siriq is intelligent, self-restrained and wise" (Ia mi sa riaseng oroané éngkaé siriqna, namapanré, namagetteng, nadéq naderi tangngaq).

Indale Patara, as the perfect Bugis man, is portrayed as having a high level of siriq. Never once does he show off, brag about his achievements or easily reveal his high birth to others. As a true Bugis man with siriq such behaviour would be inappropriate. The great praise he receives from those who do not know his noble origin is thus based on his character, actions and words. He consistently demonstrates great self-restraint and intelligence, always keeps his word, shows solidarity with others and is always brave, and never defeated by those who seek confrontation with him. As Indale Patara's journey progresses, in accordance with Bugis cultural beliefs his level of siriq constantly increases as it is linked to his morals, words, actions, honesty and self-restraint.

All of these Bugis features relating to siriq resonate in the PPIP. This contrasts with the Malay Inderaputera story where the hero constantly makes himself known to others and is quick to tell them of his high origins. Indale Patara rarely reveals his origins and never when he first meets someone, thus conforming to ideal Bugis culture that a person's standing cannot be determined from their words alone but daily behaviour, actions and personality must also be taken into account. Raja Sahesiya and his prime minister repeatedly examine these aspects of Indale Patara's character and even pay attention to the way he sleeps. Their results are consistent: Indale Patara has all the qualities and characteristics expected of a true Bugis noble. 
Other notable Bugis adaptions to the story include changing the names, features and actions of a number of the characters to ones that appear in popular Bugis stories. For example, the Nenek Kabayan of the hikayat Inderaputera becomes Kajao Pallaq, who appears in many Bugis stories as a kind, polite and moral person. Another character which appears in the PPIP is Nenek Pakande, who in Bugis stories is evil, lazy and greedy, feeds on humans and often placed in opposition to Kajao Pallaq. In the PPIP, Nenek Pakande replaces the evil man-eating giant of the hikayat Inderaputera and is defeated by Indale Patara.

\section{THE SUFI ADVENTURES OF INDALE PATARA AND THE PERFECT BUGIS MAN}

Mystical Islam has a long history in South Sulawesi and many Bugis and Makasar rulers followed the Khalwatiyya tariqa (mystical order) that was introduced by Syekh Yusuf in the second half of the 17th century (see Hadrawi 2016). The form of Islam to which South Sulawesi rulers converted at the beginning of that century also appears to have been mystical, as Thomas Gibson (2007: 45-49) has shown from his analysis of the conversion myth for the kingdom of Talloq. ${ }^{14}$ This mystical form of Islam was easily assimilated with indigenous Austronesian beliefs and made it possible to transform, yet maintain, the South Sulawesi model of divine descent from tomanurung or totompoq to an Islamic model derived from Ibn al-Arabi's concept of the "perfect man" (Gibson 2007: 39). Rulers thus retained their traditional authority as descendants of tomanurung and combined this with a form of mystical Islamic authority that many of the archipelago's rulers practiced by the 16th century.

This assimilation of indigenous and mystical Islamic beliefs can be seen in the character of Indale Patara. He is descended from a tomanurung, has all the sulapaq eppaq qualities, an immense level of siriq and practices a mystical form of Islam that many of the South Sulawesi elite followed. His journey is a spiritual jihad and before undertaking any task or action, he prays and searches his inner self for guidance. Only after he receives true guidance through prayer does he act.

The Sufi dimension of the story is evident from its beginning with the appearance of the Prophet Khaidir, ${ }^{15}$ who foretells of Indale Patara's birth and his Bugis qualities, which is disclosed to Fatahule Arifina while he is on a mountaintop praying to God that Raja Bukeroma Bisepa be given a child. The Prophet Khaidir is of particular importance to Sufis. He is believed to have received illumination directly from God and is seen as a teacher of 
secret mystical truths and spiritual knowledge. The Prophet Khaidir is said to have lived at the same time as the Prophet Musa (Moses) and most Sufi's believe he is still be alive today, appearing once in a while to chosen people who have attained a high level of religious knowledge in order to guide and teach them hidden mystical truths. Indeed, many Sufi syekhs and prominent Sufi leaders claim to have had personal encounters with him.

Indale Patara is one of the chosen few to whom the Prophet Khaidir imparts wisdom and reveals mysteries, appearing to him in various guises at different moments in the story. Sometimes he takes the form of an old learned man, as in the excerpt below, accompanied by dazzling light. The first encounter is when Indale Patara is still young and, while learning to ride, disappears in the middle of the forest.

By the will of God, he met the Prophet Khaidir, who wore a white turban. Indale Patara said: "Oh, learned one, teach me for a moment." The man replied, "[You are] Indale Patara, the son of Raja Bukeroma Bisepa." Indale Patara was startled that the man knew who he was. He replied: "Oh, you know me, learned one? The man replied: "I have known you since the time [you] were before God." Indale Patara said: "Oh learned one, pray to God for me so that I will be like my father and my mother." The man said: "In the future you will surpass your father and mother, but soon great sadness will befall the people of your land."

Indale Patara's heart jolted when he heard the words of the learned man. Tears trickled from Indale Patara's eyes and dripped on the tips of leaves. The man spoke again: "Do not cry, for it will not be difficult in the end." Indale Patara wiped away his tears. The man spoke again: "The truth is that patience comes from remembering God, you will be rewarded with happiness. Never doubt God and his kindness, always have faith and belief when there is sadness. Indale Patara felt relief after hearing the words of Prophet Khaidir, who then disappeared.

Nakarana pappatotoqna Allah Taala siduppani nabi Heléré massapu puté. Makkedai Indale Patara: E To Matoa pappédapiq manaq cinampeq. Mettéqni To Matoaé: É Indale Patara anaqna raja Bukero Misepa. Naalinganganna Indale Patara karana ri issenna ri To Matoaé. Makkedani Indale 
Patara: É To Matoa muissegga sa. Mettéqni To Matoaé makkeda: Ri olona mupa Allah Taala uissekko. Makkedani Indale Patara: É To Matoa éllau doangekkaq ri Allah Taala kutolai amakku enrengé inakku. Mettéqni To Matowaé makkeda: Mattola palalloko matti ri inammu riamammu, naé mawéq nitu natuju sara ininnawa kuaé to pa wanuannu.

Natakelleq-kelleqna ininnawanna Indale Patara méngkalingai paunna To Matowaé. Naddunuq-dunuqna uaé matanna Indale Patara. Koto mani saq anreng pettué naténré-ténré tassiampoq napolé teppa ri daung loloé uaé matanna Indale Patara. Nakkeda To Matoaé: Ajaq muterri muaseng gi majaq cappaqna. Aga nassempéanni uaé matanna Indale Patara. Nakkeda To Matowaé: Naia sabbaraqé nasilaoang parengngerang ri Allah Taala majeppu matti riwaleqi rio. Naia peddiqé nakko silaloang mui teppeqé enrengngé rennué kuaé topa décéng kapangngé ri Allah Taala déq abata-batangenna décénna. Aga namanyamenna ininnawana Indale Patara méngkalingai adanna nabi Héléréq, nalenynyeq to na ri tu.

This meeting with the Prophet Khaidir represents Indale Patara's first step of a journey towards becoming an enlightened Sufi and the perfect Bugis man. The adventure begins when the peacock flies him from his home. From then on he faces numerous trials and tests, fights in just wars, experiences love, sadness and suffering, is murdered and resurrected, until finally, he emerges as the victor who has proved himself a magnificent servant of God, a pious and learned king with no equal and the manifestation of the perfect Bugis man.

During his travels, he meets with other Sufi figures who have renounced the material world and dedicate their lives to the worship of God and seeking mystical truths. These include Ruhul Yamani (the pious man) and Jaberute (the pious woman), who Indale Patara meets on a mountaintop while she is carrying out her religious obligations to God. From them Indale Patara learns about divine wisdom, truth and spiritual knowledge as his spiritual journey progresses. He also spreads Islamic teachings imbued with Sufism wherever he stops, proclaims fatwa and aids people who are oppressed:

Indale Patara smiled then said: "My family, you should not let your existence be killed by your own bodies. For if a person uses their tongue wrongly this can kill their body. Dear family, 
do not let your tongue be separated from your body as both words and actions must be in harmony. For truly the tongue is like a boat for the body and completes the body." ${ }^{16}$ All of the people bowed their heads as they listened to Indale Patara's words. The Alawi ${ }^{17}$ then paid homage and said: "Do not leave us, lord, do not make us orphans. For we know who it is that shows the true path. It is he who became our father and our mother. We ask for this, if you go leave us food that will never decay and make us grow strong." ${ }^{18}$ Indale Patara said: "Oh, Alawi, the body is like a house. If the house is large but has no contents then it is useless. Really, the truth is that the body is just a box for jewels and they illuminate the human shell."

Nacabbiruqna Indale Patara nakkeda: É Séajikku, ia na ritu lahérengngé téa ri uno ri watang kalé. Naia tu nasala lilaé riuno nitu watang kalé. Ajaq lalo Séajing mureppaqi lilamu ri watang kalému, narékko tessituruqi gauqé apaq ia tu lilaé lopinnai tubué paréwana to i sininna watang kaléwé. Nacukuq manenna sininna to maégaé méngkalingai paunna Indale Patara. Nasompana Alawi makkeda: É Puang muwélai tongengngaq Puang mupabéuwaq Puang. Apaq uisseng niginigi patirowangeng laleng madécéng ia to ni ri tu ri poinang ri poamang. Aga uakkeda: narékko laoki tarowangengngi bokong temmawari nennia asaléwangeng. Nakkedana Indale Patara: É Alawi, ia tu tubué ébaraqi bola narékko marajai bolaé nadeq liseqna riparennajai. Apaq ia akkalengngé pettinnai paramata mallai-laingengé, sulo mattappaqna to i watang kaléwé.

Such teachings spread by Indale Patara contained within the story have strong Sufi messages, in particular, how to capture the divine truth that is hidden from the naked eye. Indale Patara learns to see these hidden mystical truths on his spiritual journey and becomes more ascetic, distancing himself from materialism as he seeks the truth. Nor does he forget his duties as a mystical Islamic leader on earth and spreads his messages to all people he meets. Through his journey he acquires a true understanding of the nature and meaning of life and of human interaction, such as marriage, the nature of the state, war, and the relationship between men and women.

In accordance with Sufi teachings, Indale Patara sees the male character as positive and the female as negative. These positive and negative characters are not permanently linked to visible differences between genders but are interchangeable as a man may have the character of a woman and a 
woman that of a man. A woman who has these male characteristics has the right for her opinions, views and decisions to be accepted. As Sachiko Murata (1992: 318) explains, in early Sufi writings there are many sayings that attribute masculinity to women and that "by calling a woman a 'man' the Sufis meant to show that she had attained to the fullness of the human state in which the soul serves the intellect." This relationship can be seen in the extract below:

Indale Patara spoke again: "Oh, Alawi, I ask a question of you. How great is your knowledge of women, how many characteristics do women have and how many do men have?" The Alawi gave homage and spoke: "It is you who know better, my lord." Indale Patara said: "Oh, Alawi, there are eight male characteristics." Raja Baredaiya asked: "What are they my child?" Indale Patara answered: "The first is honesty, the second is faith, the third intelligence, the fourth self-restraint, the fifth is happiness, the sixth is to be observant, the seventh is calmness and the eighth is to always remember God."

"If a woman has these characteristics then she is a man and her opinions are valued. Only her physical appearance is that of a woman."

"Truly a woman has these eight characteristics: refined on the outside, dirty within, hypocritical, fickle, panics, speaks impulsively, gossips, and has habits that can cause embarrassment for others. If a man has these characteristics then he is not a man [but a woman who has] the physical appearance of a man. ${ }^{19}$

Makkeda si Indale Patara: É Alawi makkutanawaq ri ko kéga gangkanna muisengngé makkunrai bettuanna siaga sipaq ri makkunraié, siaga to sipaq ri oroanéwé. Nasompana Alawi makkeda: Idiq mua Puang missengngi. Nakkedana Indale Patara makkeda: É Alawi arua ri aseng sipaqna oroanéwé. Nakkutanana Arungngé ri Baredaiya makkeda: Pégana kuaé Anaq. Metteqni Indale Patara makkeda: Séuani lempuq, maduanna teppeq, matelunna acca, maeppana perreng, malimanna rio, maennenna mattangngaqi, mapitunna temmappasilaingengngi ri pellana ri cekkéqna, maruana malampéq paréngngerangngi ri Allah Taala. 
Namau makkunrai naposipaqi makkuaéro riaseng to i orowané, essani riala tangngaqna matappa makunrainna mua.

Apaq ia makkunraié napusipaqi aruaé wuangenna, macinnong ri saliweng, marotaq ri laleng, napusipaqi mabbellé perruqi, taggiling-kilingngi, patakkinirengngi, marapo ada-adai, madécéngngi mappapolé-polé adeq riasiriqi ri sininna gauqé. Namau oroané naposipaqi makkuaéro tania tu oroané, matappa oroanémi.

\section{CONCLUSION}

The pau-pauna Indale Patara, like its Malay counterpart, is perhaps one of the great literary works of the Indonesian-Malay Archipelago. It is a story full of miraculous and amazing tales, happiness, sorrow, suffering and ultimately, spiritual victory. In this article, rather than discussing the story from a literary, philological or comparative perspective, I have specifically focused on the indigenous cultural concepts introduced by the Bugis and the assimilation of these concepts with Islam. That the Bugis felt impelled to implant their own cultural concepts at the centre of the story serves to emphasise the great strength and resilience of their culture. This strength and resilience remains evident today as many of these concepts continue to play a fundamental role in Bugis society as they have merged with Islamic values. Indeed, it is only through a combination of both Bugis and Islamic qualities and characteristics that Indale Patara was able to become the perfect man.

\section{ACKNOWLEDGEMENT}

I would like to thank Roger Tol and Stephen Druce for their helpful criticisms and informative comments on an earlier draft of this paper. 


\section{ENDNOTES}

* Nurhayati Rahman obtained her $\mathrm{PhD}$ in philology from Universitas Indonesia. She is currently Professor of Philology at Hasanuddin University, Makassar. Nurhayati has published widely on Bugis and Indonesian literature in general, including several books, such as Kearifan Lingkungan Hidup Manusia Bugis berdasarkan Naskah Meong Mpaloe, published in 2009.

1 The author wrote this article in the Indonesian language specifically for this edition of IJAPS with the agreement that the guest editor would translate and edit the text. Stephen C. Druce is the guest editor for this IJAPS' special issue on Orality, Writing and History: The Literature of the Bugis and Makasar of South Sulawesi.

2 Versions of the story are found in Sumatra, the Malay Peninsula, Lombok, the Southern Philippines and among the Chams (Braginsky 2009).

3 Makasar (with one "s") refers to the ethnic group of that name and their language; Makassar refers to the capital of South Sulawesi, formerly Ujung Pandang.

4 On Ibn al-Arabi's concept of the perfect man see Little (1987).

5 Eight other manuscript versions of the PPIP were located in this microfilm collection. Analysis of all versions showed No. 01 /MKH/ 1/Arnas/UP Rol 04 No. 1 to be the most complete, coherent and consistent. See Rahman (2014).

6 Some Bugis writers and copyists appear to have considered the PPIP a sacred work as several manuscript versions refer to the story as sureqna Indale Patara rather than pau-pauna Indale Patara. The term sureq is usually reserved for writing considered sacred or religious, such as Islamic religious stories about Koranic figures and the La Galigo epic literature that contains pre-Islamic Bugis religious beliefs and practices (Rahman 2006), whereas the term pau-pau is used for oral and written literature in general. I use the term pau-pau here as this is the term used in the manuscript upon which this study is based, as set out in the first line: Ia naé pau-paunna Indale Patara, anaqna raja Bukeroma Bisepa raja Samanta Pura amanna (This is the story of Indale Patara, the prince of Raja Bukeroma Bisepa, whose father was Raja Samanta Pura).

7 Khaidir is the Indonesian spelling of this mystical figure. He is more commonly known as Khidr or al-Khidr. I discuss him further below in relation to the Sufi aspects of the story.

8 In support of this argument it should be noted that the version of the Inderaputera story found among the Chams contains no Islamic elements (Fang 2013: 158).

9 This ideal of conflict avoidance is set out in the La Galigo epic literature: "Seven times you turn your sail to the right, seven times also to the left. If your boat is still not allowed to pass only then do you face your adversity" (Wekka pitui mutoleang sompeqmu ri atau wekka pitu toi ri abeo, tenna taropi lalo wangkangmu mupolalengngi siaq perriq) (Rahman 2006: 354).

10 Interestingly, Muhlis Hadrawi (2016) explains that the Bugis divide the female vagina into four parts, or walls, which suggest it is considered perfect. Each of the four parts is symbolically guarded by wives of the Prophet Muhammad.

11 Note that sulapaq eppaq qualities given by different scholars can have minor variations. See Mattulada (1985: 8-9) and Pelras (1996: 210).

12 The concept of tomanurung and whiteblood is also found among the Makasar, Toraja and other South Sulawesi ethnic groups. For a discussion on whiteblood in relation to the ruling elite see Pelras (1996: 169-170) and Druce (2009: 161-163). 
13 The concept of siriq is found among most ethnic groups that speak languages belonging to the South Sulawesi language family.

14 Initial conversion to Islam in South Sulawesi is attributed to three datok from Sumatra (Pelras 1985: 108). The first South Sulawesi ruler to convert to Islam was La Patiwareq of Luwuq in 1605, followed in the same year by the rulers of Gowa and Talloq.

15 There is a dispute among Muslims as to whether Khaidir should be seen as a saint rather than a prophet. In the PPIP, the term prophet is consistently used.

16 Editor's note: This passage appears to refer to the "guarding the tongue." Misuse of the tongue can lead to various sins and bring disaster or upheaval. Consequently, use must be right, honest and truthful. For Sufi's, it is the tongue that speaks the dhikr (repetition of a mystical name or phrase like Allah), which descends from the tongue to the heart then the soul and must not be false.

17 In this context the term Alawi appears to be used generally in reference to those who follow a form of mystical Islam. More specifically, it is associated with the Alawiyya or Ba'Alawi tariqa centred in Hadhramawt, Yemen, that spread to other places, including Indonesia and Malaysia, along with the Hadhrami diaspora (KathirithambyWells 2012). The Ba'Alawi tariqa was one of the many Sufi tariqa Syekh Yusuf studied and took initiations in during his time in Arabia, although it does not appear to have been of particular importance to him (Bruinessen 1991: 254-245).

18 The meaning of the metaphor in this sentence is to leave behind mystical knowledge and truths in the spiritual path or way towards God.

19 Editor's note: the notion that these male and female characteristics can be applied to either gender shares many similarities with what are seen as indigenous Bugis cultural ideas relating to the relationship between women and men, particularly the idea that some women can have male characteristics (see Mangemba 1975). It is possible that these Sufi ideas were assimilated with a still relatively common feature of Bugis society, the calabai (false women), who are male transvestites, and calalai (false men), the female equivalent. In a recent paper, Druce (2015) discusses male and female characteristics, their interchangeability, and the relationship between men and women in general in the context of the numerous Bugis female rulers in history.

\section{REFERENCES}

Ahmad, A. 1975. Hikayat Inderaputera, 3rd ed. Kuala Lumpur: Dewan Bahasa dan Pustaka.

Braginsky, V. 2004. The heritage of traditional Malay literature: A historical survey of genres, writings and literary views. Leiden: KITLV Press.

. 2007. Pengenalan II. Hikayat Inderaputera: Dongeng indah dan perbendaharaan rahsia. In Hikayat Inderaputera, eds. Mulyadi, S. W. R. and Braginsky, V., xlix-clxii. Kuala Lumpur: Yayasan Karyawan.

. 2009. Dua pengembaraan hikayat Inderaputera. In Sadur: Sejarah terjemahan di Indonesia dan Malaysia, ed. Chambert-Loir, H., 975-1000. Jakarta: Kepustakaan Populer Gramedia. 
Bruinessen, M. V. 1991. The tariqa Khalwatiyya in South Celebes. In Excursies in celebes: Een bundel bijdragen bij het afscheid van J. Noorduyn als Directeur-Secretaris van het Koninklijk Instituut voor Taal-, Land- en Volkenkunde, eds. Poeze, H. A. and Schoorl, P., 251-269. Leiden: KITLV Press.

Druce, S. C. 2009. The lands west of the lakes: A history of the Ajattappareng kingdoms of South Sulawesi, 1200 to 1600 CE. Leiden: KITLV Press. . 2015. The Bugis queens and female aristocrats of South Sulawesi. Paper presented at the Southeast Asian Studies in Asia 2015 Conference, organised by the Consortium for Southeast Asian Studies in Asia, 12-13 December 2015, Kyoto, Japan.

Fang, L. Y. 2013. A history of classical Malay literature. Singapore: ISEAS \& Pustaka Yayasan Obor Indonesia.

Gibson, T. 2007. Islamic narrative and authority in Southeast Asia from the 16th to the 21st century. New York: Palgrave Macmillan.

Hadrawi, M. 2016. Narratives of sexuality in Bugis and Makasar manuscripts. In Orality, writing and history: The literature of the Bugis and Makasar of South Sulawesi, ed. Druce, S. C. International Journal of Asia Pacific Studies 12 (Supp.1): 187-206, http://dx.doi.org/10.21315/ijaps2016.12.s1.9.

Hamid, A. 1985. Manusia Bugis-Makassar: Satu tinjauan historis terhadap tingkah laku dan pandangan hidup manusia Bugis Makassar. Jakarta: Inti Idayu.

Kathirithamby-Wells, J. 2012. Hadhrami projections of Southeast Asian identity. In Anthony Reid and the study of the Southeast Asian past, eds. Wade, G. and Tana, L., 271-302. Singapore: Institute of Southeast Asian Studies.

Little, J. T. 1987. Al-Insan al-Kamil: The perfect man according to Ibn al-'Arabi. Muslim World 77 (1): 43-54, DOI: 10.1111/j.1478-1913.1987.tb02785.x.

Mangemba, D. H. 1975. Le statut des femmes Bugis et Makassar vu par leurs propres sociétés. Archipel 10: 153-157.

Mattulada, 1985. Latoa: Satu lukisan analitis terhadap antropologi politik orang Bugis. Yogyakarta: Gadjah Mada University Press.

Mulyadi, S. W. R. 1983. Hikayat Indraputra: A Malay romance. Dordrecht: Foris.

Mulyadi, S. W. R. and Braginsky, V., eds. 2007. Hikayat Inderaputera. Kuala Lumpur: Yayasan Karyawan.

Murata, S. 1992. The Tao of Islam: A sourcebook on gender relationships in Islamic thought. Albany: State University of New York Press.

Paeni, M. et al. 2003. Katalog induk naskah nusantara Sulawesi Selatan. Jakarta: Arsip Nasional R.I. (ANRI) Jakarta.

Pelras, Ch. 1985. Religion, tradition and the dynamics of Islamization in SouthSulawesi. Archipel 29 (1): 107-135. . 1996. The Bugis. Oxford: Blackwell. 
Rahman, N. 2014. Pau-paunna Indale Patara: Dari Hindu India, Islamisasi Melayu, sampai ke sufisme Bugis. Makassar: La Galigo Press. . 2006. Cinta, laut, dan kekuasaan dalam epos La Galigo. Makassar: La Galigo Press.

Tol, R. 2008. Dampak Melayu di Sulawesi Selatan. Paper presented at the Seminar, Festival, dan Dialog Budaya Internasional Kemelayuan di Indonesia Timur, 12-13 October 2008, Makassar, Indonesia. 